\title{
Regionalne środowiska literackie i oficyny wydawnicze w polityce władz Polski Ludowej w latach 1956-1989, red. Evelina Kristanova, Szczecin-Warszawa 2020
}

(c) $\underset{\mathrm{BY}}{\left(\mathrm{ND}_{\mathrm{ND}}\right.}$ http://dx.doi.org/10.12775/KLIO.2021.033

W ostatnim czasie, w ramach znanej serii „Dziennikarze - Twórcy Naukowcy”, ukazała się nowa pozycja o charakterze zbiorowym, zatytułowana Regionalne środowiska literackie i oficyny wydawnicze w polityce wtadz Polski Ludowej w latach 1956-1989'. Trudu redakcji dzieła podjęła się dr hab. Evelina Kristanova, profesor Akademii Ekonomiczno-Humanistycznej w Warszawie.

$\mathrm{Na}$ dzieło złożyło się osiem tekstów, których autorami są przedstawiciele różnych ośrodków naukowych i różnych dyscyplin - historii, medioznawstwa, filologii, politologii, bibliotekoznawstwa czy prasoznawstwa. Całość pracy dopełniają wstęp, noty o autorach, wykaz skrótów i indeks nazwisk.

We wstępie Kristanova zwróciła szczególną uwagę na problem samego pojęcia regionalizmu, jak również podjęła próbę ustalenia wyczerpującej i możliwie najtrafniejszej definicji tegoż terminu. Ponadto zaakcentowała

1 Praca została zrealizowana w ramach centralnego projektu badawczego IPN „Władze PRL wobec środowisk twórczych, dziennikarskich i naukowych”, którego koordynatorem jest dr hab. Sebastian Ligarski, pełniący jednocześnie funkcję naczelnika OBBH IPN w Szczecinie. 
tradycje ruchu regionalnego oraz podkreśliła jego wagę, znaczenie i wkład w obecny kształt przede wszystkim kultury, ale również nauki. Autorka przybliżyła także czytelnikom powojenne dzieje takich regionalnych inicjatyw i wskazała 1956 r. jako przełomowy w ich działalności. Od tego bowiem momentu, aż do 1989 r., wyraźnie ulegały one upartyjnianiu. W ten sposób redaktorka uzasadniła decyzję o wyborze zasygnalizowanej w tytule pracy cezury czasowej.

Kristanova zmierzyła się z pytaniem o faktyczny stan i sytuację lokalnych inicjatyw. Zauważyła przy tym, iż były one wykorzystywane przez władze Polski Ludowej do „budowania przede wszystkim jednolitej i kontrolowanej "kultury socjalistycznej“”, zaś sam regionalizm „stał się wyraźnym narzędziem władzy i pretekstem do wdrażania ideologii zgodnej z polityką państwa”. W konsekwencji ruch regionalny miał być jedynie "pretekstem do wychowania "nowego człowieka» socjalizmu w danych regionach", a wydawane za sprawą tegoż ruchu organy prasowe wyraźnie te tendencje odzwierciedlały.

Zasadniczą część pracy otwiera tekst Jolanty Laskowskiej zatytułowany Gdański ruch wydawniczo-prasowy w latach 1956-1989. Wydawane w Trójmieście periodyki i druki zwarte nie były wyjątkiem i aktywnie uczestniczyły w propagowaniu przyjaznych stosunków z ówczesnym Związkiem Radzieckim. Ponadto w obawie przed niemieckim rewizjonizmem gdańska prasa silnie akcentowała polskość Gdańska i Pomorza. Z perspektywy władz Pomorze Gdańskie wymagało też szczególnej „troski”, ponieważ bardziej niż inne regiony było zagrożone wpływami z zagranicy.

Laskowska dokonała przeglądu funkcjonujących w omawianym czasie w Trójmieście poszczególnych oficyn wydawniczych, zwróciła przy tym uwagę, że oprócz prasy systemowej nie zabrakło w nim również wydawnictw drugoobiegowych. Jak się jednak okazało, mimo całkiem prężnie rozwijającego się gdańskiego rynku książki nie zaspokajał on potrzeb regionu i wielu autorów było zmuszonych szukać wydawnictw poza miastem. Dalej autorka wymieniła najpopularniejsze w tym czasie w Gdańsku tytuły prasowe i zobrazowała, jak kształtowały się one w ciągu lat. Wskazała rolę, jaką odegrała powołana w 1958 r. Komisja do spraw Wydawnictw Prasowych i Sprzedaży Czasopism, której kluczowym zadaniem było ujarzmienie nadmiernej swobody, jaką od października 1956 r. chwilowo cieszyła się prasa. 
To właśnie podczas tej popaździernikowej „odwilży” nastąpił wyraźny progres gdańskiego regionalizmu, którego owocem był m.in. powołany w lipcu 1957 r. społeczno-kulturalny magazyn o tematyce kaszubskiej, a zatytułowany „Kaszëbë”.

Co oczywiste, przełomowym momentem nie tylko dla branży wydawniczej było wprowadzenie w 1981 r. stanu wojennego, w wyniku którego zawieszonych zostało większość dzienników i czasopism. Gdańsk odczuł to wyjątkowo dotkliwie, na długie lata uczyniono go jedynym miastem wojewódzkim pozbawionym własnego pisma kulturalno-artystycznego i dokonano weryfikacji środowiska dziennikarskiego.

Bydgoski rynek książki scharakteryzował z kolei Stefan Pastuszewski, który skupił się głównie na publikacjach o charakterze literackim tego miasta i opublikował tekst pt. Poza rozdzielnikiem... Literacki ruch wydawniczy w Bydgoszczy w latach 1956-1989. Badacz krótko omówił nie tylko ówczesną sytuację wydawnictw regionalnych, ale również rozwój życia kulturalnego w regionie. Zwrócił uwagę na fakt, iż Bydgoszcz była jednym z kilku miast wojewódzkich, które nie miały swojego wydawnictwa. Taka sytuacja - zwłaszcza na początku omawianego okresu - przysparzała licznych trudności głównie dla początkujących, jak i z jakichś względów wyalienowanych autorów.

Jak zrelacjonował Pastuszewski, istotnym dla Bydgoszczy z punktu widzenia poligrafii wydarzeniem było utworzenie w mieście w 1974 r. oddziału działającego w Gdańsku Wydawnictwa Morskiego. Wyjaśnił też, jak wpłynęło ono na życie literackie i sytuację literatów miasta nad Brdą.

Autor omówił też konsekwencje dla branży drukarskiej kryzysu gospodarczego, jaki przypadł na przełom lat 70. i 80. XX w., i dość szczegółowo zobrazował kwestię Kujawsko-Pomorskiego Towarzystwa Kultury, które w 1989 r. zostało przeorganizowane w Ośrodek Kultury Regionalnej. Naświetlił znaczenie odbytego w 1961 r. jego I Zjazdu.

Artykuł jest dość obszerny i porusza wiele ciekawych zagadnień. Piszący go osobiście uczestniczył w niektórych omawianych przez siebie przedsięwzięciach. Niemniej jednak można odnieść wrażenie, że nie zawsze panuje nad tekstem. Niejednokrotnie przekracza górną granicę chronologiczną, przytaczając przy tym dość rozbudowane cytaty. Zdarza się też, że omawia wątki bardzo luźno związane z tematem. Dodatkowo posługuje 
się anglicyzmami i zdaniami wielokrotnie złożonymi, przez co narracja jest nieco chaotyczna i trudna w odbiorze. Daje się również zauważyć brak konsekwencji, choćby w przypadku wymienianych nazwisk, przy których wybiórczo pojawia się data urodzenia bohatera.

$\mathrm{Na}$ znacznie mniejszy zakres chronologiczny zdecydował się Sławomir Formella, który przygotował rozdział pt. Warunki rozwoju literatury kaszubsko-pomorskiej w latach siedemdziesiatych XX w. w świetle materiatów archiwalnych SB. W tekście pobieżnie przedstawiona została historia kaszubskiego ruchu regionalnego. Jak zauważył autor, szczególną rolę w tym zakresie odegrało Zrzeszenie Kaszubsko-Pomorskie, w którym ówczesne władze upatrywały potencjalne narzędzie do forsowania komunistycznej ideologii. Zrzeszenie szybko znalazło się w orbicie zainteresowań SB. Dzięki temu zachowała się pokaźna dokumentacja. W ten sposób możliwe stało się odtworzenie tła rozwoju kaszubskiej kultury i literatury w zasygnalizowanych w tytule ramach chronologicznych. Naświetlono też liczne kłopoty, z jakimi musiała zmierzyć się organizacja, i sposoby „bezpieki” na skuteczne utrudnianie realizacji podejmowanych przez nią przedsięwzięć.

Autor szczególnie dużo miejsca poświęcił Spotkaniom Twórców Literatury Kaszubsko-Pomorskiej, a zwłaszcza pierwszemu z nich. Podyktowane to zostało faktem, że najwyraźniej uroczystość ta była dobrze „zabezpieczona operacyjnie" i właśnie z tego przedsięwzięcia zachowała się najbogatsza dokumentacja. Dzięki niej i opracowaniu Formelli czytelnik ma okazję poznać metody pracy SB, w tym także działania mające na celu obniżanie rangi i znaczenia niewygodnych dla władz uroczystości o tym charakterze.

W trakcie lektury tego intrygującego artykułu można jednak odnieść wrażenie, że autor najwyraźniej traktuje terminy „gazeta” i „czasopismo” jako synonimy, gdyż używa ich zamiennie w odniesieniu do „Zrzesz Kaszëbskô". Tymczasem dla prasoznawcy każde z tych pojęć ma inne znacze$n^{2}{ }^{2}$. Wspomniany tytuł jako gazetę można traktować tylko w pierwszym okresie jego istnienia, gdyż tylko wtedy ukazywał się częściej niż raz w tygo-

2 W polskim systemie prawnym za gazetę uważa się periodyk ukazujący się częściej niż raz w tygodniu (S. Dz[iki], Gazeta, w: Encyklopedia wiedzy o prasie, red. J. Maślanka, Wrocław 1976, s. 91-94), czasopismem nazywa się zaś wydawnictwa, których częstotliwość ukazywania się nie jest większa niż raz na siedem dni (Czasopismo, w: ibidem, s. 60). 
dniu. W okresie późniejszym amplituda jego periodyczności ulegała zmianom, ale nie pozwalała już na nazywanie go gazetą.

Opracowania równie interesującego zagadnienia podjęła się Jadwiga Sadowska, która głównie na podstawie kolejnych roczników „Ruchu Wydawniczego w Liczbach" zobrazowała Udziat wydawców niezawodowych (tzw. nieprofesjonalnych) $w$ rozwoju polskiego rynku wydawniczego w PRL $w$ świetle statystyki. Autorka wykazała, że liczba wydawców niezawodowych była ok. 10 razy wyższa niż wydawców zawodowych, jednak grupa ta rzadko publikowała więcej niż jeden tytuł rocznie. Zauważyła też, że te z reguły amatorskie wydawnictwa mogły wprawdzie poszczycić się szerokim asortymentem i całkiem dużą liczbą drukowanych tytułów (zdarzało się bowiem, że przekraczały nawet 50\% ich ogólnej liczby), jednak nakłady tych dzieł były na ogół niskie i stanowiły niecałe $10 \%$ całej produkcji wydawniczej.

Sadowska zwróciła uwagę, że rynek druków niezawodowych rozwijał się bardzo dynamicznie i zdaniem aparatu władzy wymagał większego planowania. W związku z tym państwowa polityka wydawnicza była stale ukierunkowywana na systematyczne przejmowanie nadzoru także nad tym sektorem gospodarki, a formy kontroli przyjmowały różną postać. W omawianym artykule dokonano nadto przeglądu tytułów ukazujących się za sprawą wydawnictw stanowiących przedmiot badań. Okazało się, że były to głównie podręczniki akademickie, prace zawodowe, naukowe i popularnonaukowe.

Mimo dość specyficznej tematyki, jaką jest statystyka rynku księgarskiego, praca nie ma wyłącznie charakteru zestawienia liczbowego i analizy zebranych danych, ale przede wszystkim daje uporządkowany i przejrzysty obraz ówczesnego ruchu wydawniczego. Naświetla zachodzące w nim zmiany, wyjaśnia ich przyczyny i przybliża owoce nieprofesjonalnych działań tego typu.

Ksztaltowanie kultury ksiażki w ramach majowych „Dni Oświaty” w województwie krakowskim ws świetle „Dziennika Polskiego" w latach 1957-1987 to tytuł następnego tekstu, autorstwa Renaty Knyspel-Kopeć. W jego wstępie naświetlona została geneza wykreowanych przez komunistyczne władze, a odbywających się od 1946 r., wydarzeń kulturalnych, które w 1974 r. przyjęły rozwiniętą nazwę Dni Kultury, Oświaty, Książki i Prasy. Przytoczono również krótką charakterystykę jednej z najpopularniejszych w Krakowie gazet, jaką był ukazujący się od 1945 r. „Dziennik Polski”. Redakcja 
nie tylko relacjonowała przebieg uroczystości i zamieszczała wywiady z licznymi przedstawicielami branży księgarskiej, ale także chętnie włączała się w niektóre realizowane w ramach „Spotkań” przedsięwzięcia. Jak zauważyła Knyspel-Kopeć, dużo miejsca poświęcano tym punktom programu, które z założenia miały przynieść trwałe dla życia kulturalnego skutki - otwarciu bibliotek, świetlic czy domów kultury. Jednak ze szczególnym entuzjazmem podkreślano wkład władzy ludowej w walkę z analfabetyzmem, w popularyzację kultury i upowszechnianie szkolnictwa.

Opracowania kolejnego zagadnienia poruszonego w recenzowanej pracy podjął się Mieczysław Kopeć, który przybliżył czytelnikowi temat Nauki historii w stużbie partii wtadzy na podstawie dokumentacji procesu wydawniczego publikacji zleconej przez KW PZPR w Zielonej Górze. Aby podjąć próbę odpowiedzi na pytanie, jak w ustroju komunistycznym faktycznie wyglądał obiektywizm naukowy, autor zapoznał się z zachowaną dokumentacją, wśród której znalazła się m.in. korespondencja przychodząca z Wydziału Propagandy i Agitacji KC PZPR do I Sekretarza KW PZPR w Zielonej Górze. Jak zauważył Kopeć, Wydział Propagandy miał świadomość, że ranga publikacji naukowych ma szczególną moc i ogromny potencjał, jeśli chodzi o kształtowanie postrzegania rzeczywistości. Zdawano sobie sprawę z tego, że druki powstałe na podstawie zasobów archiwalnych sprzyjają naukowej wiarygodności. W związku z tym podczas przygotowań takich dysertacji, zestawiano w nich te dane, które stawiały ówczesne władze w bardzo korzystnym świetle. Z centrali do terenowych oddziałów napływały bowiem wskazówki, w jaki sposób manipulować danymi, by wynikały z nich tylko pożądane przekazy.

Kolejny - tym razem napisany w stosunkowo barwny i lekki sposób - tekst powstał nie tylko dzięki dociekliwości badawczej, ale również osobistemu zaangażowaniu w sprawę Wojciecha Kajtocha. Przygotowany bowiem przez niego materiał Poza "centrum”, czyli historia ocenzurowania i konfiskaty antologii poetyckiej "Starty" traktuje o licznych, w tym także nie do końca zrealizowanych, przedsięwzięciach edytorskich jego ojca - Jacka Kajtocha. Autor zaprezentował główne literacko-naukowe zainteresowania swego przodka i wskazał największe jego osiągnięcia.

Największy ciężar pracy spoczął jednak na losach antologii Starty. Manifesty i wypowiedzi programowe mtodych poetów 1960-1974, która mimo 
bardzo zaawansowanego etapu prac nie doczekała się publikacji. Ponieważ autor dysponował dwiema wersjami wspomnianego zbioru poezji: zarówno tą przygotowaną przez krakowskiego edytora w 1975 r., jak i tą już ocenzurowaną i przeznaczoną do druku z 1977 r., dokonał wnikliwej ich analizy i skrupulatnego porównania. Rozważył także potencjalne przyczyny, które stanęły na drodze finalizacji tej inicjatywy.

Mimo niezwykle intersującego ujęcia tematu i wielu ciekawych wniosków praca nie jest wolna od drobnych usterek. Największą z nich - zdaniem piszącej te słowa - jest bez wątpienia zakwalifikowanie przez autora wykorzystanych źródeł do opracowań. Tymczasem w sytuacji, w której przedmiotem pracy jest dorobek Kajtocha, dzieła tego edytora bezwzględnie należy traktować jako źródła!

Ostatni - opracowany przez Evelinę Kristanovą - rozdział został poświęcony wydawanemu w Szczecinie Regionalnemu miesięcznikowi spoteczno-kulturalnemu „Spojrzenia” (1971-1973). Autorka przybliżyła genezę tego periodyku, scharakteryzowała grono jego twórców, dokonała analizy prasoznawczej i przedstawiła najczęściej podejmowane na jego łamach zagadnienia. Przygotowując ten artykuł, autorka opierała się nie tylko na poszczególnych numerach czasopisma, ale zapoznała się również z zachowaną w AAN i IPN dokumentacją na jego temat. Pewne wątpliwości może budzić fakt, że tytuł artykułu jednoznacznie wskazuje, że przedmiotem pracy będą numery wydane w latach 1971-1973, tymczasem - jak zaznaczyła Kristanova - czasopismo ukazywało się do 1974 r. i ten ostatni rocznik również został objęty analizą. Czytelnika może uderzać zatem rozbieżność w datach, która - niewykluczone - wyniknęła jedynie z błędu literowego w tytule, zwłaszcza że autorka w żaden sposób do braku tej spójności się nie odniosła.

$\mathrm{Na}$ koniec kilka uwag odnoszących się do całej pracy. Niestety nie jest ona wolna od drobnych potknięć, niedopatrzeń i usterek. Szkoda np., że nikt przed jej publikacją nie zwrócił uwagi na to, że tak, jak nie może narodzić się kilkuletnie dziecko, tak samo nie może powstać „kilkuletnie pismo" (s. 205). Jeszcze większe zastrzeżenia mogą budzić stosowane skróty. Do pracy wprawdzie załączony został ich wykaz (chociaż jak się okazuje - niekompletny), jednak jeśli chodzi o tekst zasadniczy, system ich stosowania jest chaotyczny i w ogóle nieuporządkowany. Dobrze jest przyjąć 
zasadę, że pełną nazwę skracanych następnie zwrotów piszemy wówczas, gdy używamy ich po raz pierwszy, jednocześnie wprowadzając ich skrót $\mathrm{w}$ nawiasie. Tymczasem w recenzowanej publikacji zdarzają się sytuacje, w których dany skrót występuje kilkakrotnie, a dopiero z czasem zostaje wyjaśniony.

Dopracowania domaga się również stosowany aparat naukowy, a zwłaszcza bibliografia załącznikowa. Przede wszystkim bezzasadne jest wyodrębnianie kategorii „opracowania i artykuły”, gdyż podział powinien przebiegać według treści, a nie formy. Przecież artykuł może być zarówno źródłem, jak i opracowaniem. I to właśnie źródła i opracowania stanowią dwa zasadnicze elementy, które winny znaleźć się w każdej bibliografii. Podobne zastrzeżenia można mieć do pojawiającej się w przypadku niektórych tekstów kategorii „źródła internetowe”, które de facto najczęściej są opracowaniami umieszczonymi w internecie. Jeśli autor bądź redaktor widzi potrzebę odseparowania pozycji elektronicznych od tradycyjnych, bardziej zasadny wydaje się podział na literaturę drukowaną i netografię.

W kontekście tematyki tomu nie powinno się także wydzielać „prasy”, ponieważ gdy przedmiotem analizy jest czasopismo, jak to było w przypadku tekstów Knyspel-Kopeć i Kristanovej, jego poszczególne numery również należy traktować jako źródło. Ponadto bibliografie załącznikowe nie uwzględniają wszystkich cytowanych dokumentów. Dotyczy to głównie tekstu Sadowskiej, która powołuje się na dekrety, ustawy i rozporządzenia, ale nie odnotowuje ich w wykazie literatury. Podobnie rzecz się ma z indeksem osobowym, który pomija wiele występujących w poszczególnych opracowaniach nazwisk.

Mimo wskazanych powyżej usterek recenzowaną publikację należy uznać za cenne wydawnictwo. Podjęte przez grono jej autorów badania zaowocowały sformułowaniem wielu ciekawych wniosków, w rezultacie czego praca stanowi istotny wkład w rozwój badań ruchu wydawniczego PRL, poszerzając i systematyzując wiedzę na temat funkcjonowania zarówno oficyn, jak i środowisk literackich w latach 1956-1989.

Barbara Centek (Toruń)

ORCID: 0000-0002-9600-3067 